\title{
The logical meanings of the traditional wedding speeches of the Batak Toba people
}

\author{
Sanggam Siahaan, Selviana Napitupulu, Albert Tony, Sahlan Tampubolon \\ English Language Teaching Study Program, Teacher Training Faculty, Universitas HKBP Nommensen, Medan-Pematangsiantar, \\ Indonesia
}

\author{
Email address: \\ siahaansanggam@yahoo.com (S. Siahaan)
}

\section{To cite this article:}

Sanggam Siahaan, Selviana Napitupulu, Albert Tony, Sahlan Tampubolon. The Logical Meanings of the Traditional Wedding Speeches of the Batak Toba People. International Journal of Language and Linguistics. Vol. 2, No. 5, 2014, pp. 328-342.

doi: $10.11648 / \mathrm{j} . \mathrm{ij} 11.20140205 .16$

\begin{abstract}
This research deals with the logical meanings of the clause complexes in the Batak Toba People wedding speeches. The problem investigated deals with the types of the logical meanings existed in the traditional wedding speeches of the Batak Toba people and the way each of those types is created. The theoretical frameworks in this research are the logical meanings and the logico-semantic relation theories. The research design refers to an object as multiple realities as a qualitative research. The research subject is the Batak Toba people creating the wedding speeches in the wedding ceremony. The object is the logical meaning in the structure of a clause complex. The data are 142 clause complexes from the 15 recorded wedding speeches. The technique of the data collection and analysis follow the concept of the researcher concurrent activities, they are data collection, reduction, display, and drawing conclusion. The findings are that the logical meanings the Batak Toba people wedding speeches are expansion, such as elaboration, extension, and enhancement; and projection, such as locution projection, idea projection and idea.
\end{abstract}

Keywords: Logical Meaning, Logico-Semantic Relation, Clause Complex

\section{Introduction}

\subsection{Background}

This research is about the logical functions which are created by the logico-semantic relation of the clause simples in the clause complexes which exist in the wedding speeches of the Batak Toba people. The main problem investigated concerns with the types of the logical meanings, the way each of them is created in the context of the clause complexes, and the reason why their specific types dominate the wedding speeches. The realization of the clause simples in a clause complex as the context of a specific logical meaning is defined as a text. It is said that context can be a linguistic context or a nonlinguistic context.

The findings of this research have two types of significance i.e. theoretical significance and practical significance. Theoretically, the findings of this research may have some significances, they are that the findings can be very important information for the conceptual development of the logical meaning created by the clause simples in the clause complexes; and they can be used to understand how the clause simples enter into the clause complexes and create the logical functions in the clause complexes. Practically, the findings may have some significances, such as that the findings can be used by linguistic theorists to improve the concept of how language works to function in their context; and the findings can be used by people to create and interpret the logical function in the traditional wedding speech of the Batak Toba traditional wedding party.

In accordance with the context given above, the statements of the research problems which are investigated in this study are as follows: 1 . What are the types of the logical meanings which exist in the traditional wedding speeches of the Batak Toba people? 2. How is each of the types of the logical meanings created in the traditional wedding speeches of the Batak Toba people? The research objectives are to invent all the types of the logical meanings 
which exist in the traditional wedding speeches of the Batak Toba people and to know how each of the types of the logical meanings is created in those speeches.

\section{Related Literature}

\subsection{Theoretical Frameworks}

Logical meaning is the logico-semantic relation of some clauses in a clause complex. Halliday (1994) says that clause complexes can be viewed from the tactic and logicosemantic relation systems. By tactic system, clause complexes are divided into the paratactic and the hypotactic systems. The paratactic system refers to the clause complex in which each of the clause simples is independent to each other in it. Each of them has equal status. The status of a clause is not dependent toward another one. Each of the clauses in the paratactic system is symbolized by number. If a paratactic system has two clauses, so the first clause is symbolized by number 1 and the second one is symbolized by number 2 . For instance "Mary has some friends; Susan is one of them" is a clause complex of the paratactic system with two independent clauses. Here it is symbolized by 12 as in " 1 Mary has some friends; 2 Susan is one of them". If the clause has more than three clauses such as "Mary has two friends; her first friend is Susan; the second is Jill.", so it is symbolized by 123 as in " 1 Mary has two friends; 2 her first friend is Susan; 3 the second is Jill. The hypotactic system refers to the clause complex in which the clauses in it have interdepency relation. It means that the relation of a clause to another clause is according to their status. A clause can be independent in which its presence in a clause complex does not depend on the existence of another clause. A clause can be dependent in which its presence in a clause complex depends on the existence of another clause. An independent clause is symbolized by $\alpha$. A dependent clause which is not necessarily embedded in the independent one is symbolized by $\beta$. Another dependent clause within $\beta$, but which is not necessarily embedded in it is symbolized by $\gamma$. The other dependent clause within $\gamma$, but which is not necessarily embedded in it, is symbolized by $\delta$. So the continuation of the first clause up to the last one is symbolized by $\alpha \beta \gamma \delta$. For instance each of the clauses in a clause complex such as "Mary who loves john the young man who works in my father's company which its head quarter is in this city is my sister." is symbolized as in " $\alpha$ Mary is my sister; $\beta$ who loves john the young man; $\gamma$ who works in my father's company; $\delta$ which its head quarter is in this city." In a real text i.e. spoken and written text, the stretches of the clauses in a clause complex such as in the example above create a block of meanings in which the structure or pattern of logical functions or meanings can be analyzed. Halliday (1994), logical meanings are divided into expansion such as elaboration, extension and enhancement and projection such as idea and locution.

Elaboration is divided into specification, exemplification, restatement, and commentary. Specification refers to the function of a clause to expand the meaning of another clause by elaborating the meaning of the whole clause or part of the clause into a specific meaning in a nexus. Exemplification refers to the function of a clause to expand the meaning of another clause by elaborating the meaning of the whole clause or part of the clause into some examples in a nexus. Restatement refers to the function of a clause to expand the meaning of another clause by elaborating the meaning of the whole clause or part of the clause into a restatement in a nexus. Commentary refers to the function of a clause to expand the meaning of another clause by elaborating the meaning of the whole clause or part of the clause into a commentary.

Extensions are divided into extension with "and" or "but". Extension with "and" refers to the function of an "and-clause" to expand the meaning of another clause by extending its meaning into a new one. Extension with "but" refers to the function of a "but-clause" to expand the meaning of another clause by extending its meaning into a new one.

Enhancements are classified into six. The first is spatial which refers to the function of a clause to expand the meaning of another clause by enhancing it with a spatial meaning. The second is temporal which refers to the function of a clause to expand the meaning of another clause by enhancing it with a temporal meaning. The third is conditional which refers to the function of a clause to expand the meaning of another clause by enhancing it with a conditional meaning. The fourth is causal which refers to the function of a clause to expand the meaning of another clause by enhancing it with a causal meaning. The fifth is concessive which refers to the function of a clause to expand the meaning of another clause by enhancing it with a concessive meaning. The sixth is manner which refers to the function of a clause to expand the meaning of another clause by enhancing it with a manner meaning.

Projections are classified into locution and idea. A locution is differentiated from an idea based on the process used in their projecting clause.

Locution refers to the function of a clause to be projected by a projecting clause through wording the projected clause. A locution is projected by a projecting clause with a verbal process.

The concept of text emerges from some concepts given by some theorists. Halliday and Hasan (1976: 1-2) says that a text refers to any unified spoken or written passage in use as a whole, not as in the length of a grammatical unit like a clause or a sentence, but it is regarded as a semantic unit; a unit not of form but of meaning. This concept concentrates on the meaningful unit of a spoken or written language in use i.e. in context. They also say that it is a living language which plays some part in a context and it is a social interactive event or social exchange of meanings (Hasan and Halliday, 1985). This implies that a text must not be separated from its environment, but it is a live language in its context of use. Then Halliday (1985/1994: xvii) also says that a text is a semantic unit, not a grammatical one. It 
is said that meanings are realized through wordings; and without a theory of wording - that is grammar - there is no way of making explicit one's interpretation of the meaning of a text. This refers to the first context of a text i.e. grammar which governs the use of the text in co-text. It implies that grammar is responsible to provide the grammatical meaning of a text.

Hatim and Mason (1990) say that a text is a set of mutually relevant communicative functions which is structured in such a way to achieve an overall rhetorical purpose. This explains that the communicative function of a text works together with the structure of the text. It also explains that the structure of the text flows logically to achieve its rhetorical purpose. Here the structure is seen to deal with a purpose to narrate an event in the past or in the future, or to describe an object such as a place or a thing or a human, or to convince the readers in order to believe or disbelieve a case or to present an argumentation that something is the case. The logical flow in such a text is commonly created by cohesion ties such as noun substitute, pronoun, connector such as and, or, and but or conjunction such as first, next, afterward, after that, further, in addition to that, beside etc. Here a text is defined as a set of mutual relevant communicative function which is logically structured to achieve its rhetorical purpose.

A text is made up of sentences, but there exist separate principles of text construction, beyond the rules for making sentences. This means that the principle of the text construction is beyond the principles of the sentence construction. It means that the construction of a text does not only refer to the word order in a sentence, but it refers to the relation of the meaning to its contextual aspects. This theory relates a text to its contextual aspects where the text is created. It focuses on how the meaning of a text is created in which the meaning is believed to be created in relation to the contextual aspects. It is seen that what is seen is the physical realization of the text, and the text itself is beyond the physical representation. It is concluded that the principle of the construction of the physical representation of the text is separated from the principle of the construction of the text itself.

Neubert (1992) says that a text is the tool to communicate something to someone. This implies that a text is a tool to communicate meanings in a social exchange. What is focused here is the separation between two things as the aspects of a text. The first is something which is communicated. This first component is the meaning of the text. It is the thing which is negotiated by the speaker to the listener in the spoken text, or by the writer to the reader in the written text. In a real communicative interaction, what is communicated is the message. The second is what tool is used to communicate the meaning or the message. This second component is the linguistic realization of the text. This can be a word or a word group or a clause or the one which is bigger that a clause. It is concluded that a text meant here does not only refer to a component of the text itself, but it refers to the two side of the text, they are the meaning and the language form as the tool which is used to communicate the meaning.

The term "context" refers to three theoretical concepts. First, it refers to co-text which is called as the linguistic context. With this concept, context refers to the linguistic unit either in front or behind the text. Second, it refers to the first non-linguistic context which envelopes a text with its co-text. It is the context of situation which is also called as register. It has three variables i.e. field, tenor, and mode. These three components work as a set of network system which activates the meaning of a text. Third, it refers to the context of culture which is called as genre. It is the outer context which activates the meaning of the text in its cotext and context. Its variables can be purpose-goal and purpose-outcome, belief, ideology etc. As an instance the clause "she is a very talented girl" in "Mary plays flute miraculously; she is a very talented girl." has a function as a commentary elaboration expansion. It means that it function to provide a commentary while it works to expand the meaning of its context by elaborating it on the level of context. In the context of register, the field of "Mary plays flute miraculously; she is a very talented girl." is about Mary as a very talented musician girl. In the tenor relation between an advertiser and a perspective fan, the interpersonal function of the text is to provide a piece of information about "Mary as a very talented musician girl". In the culture of the advertiser and the prospective fan, they learn from their custom that such a thematic structure, for instance, is used by the advertiser to convince the fans to come the music concert which is presenting Mary the very talented musician girl. It can be concluded that a text is a unit of language which has a set of meanings when it is placed in both linguistic context which is also called co-text and non-linguistic context i.e. register and genre.

The theoretical framework above firstly emerges from the idea of Manfredi (2008: 38) saying that "we do not refer to the general meaning of a text around our text, for which we use the term 'co-text'; we refer to a precise and specific concept. Here, it is said that co-text refers to linguistic context, around a text, which creates the general meaning of the text. The she goes on saying that the notion of context is viewed from two different perspective: firstly, from the point of view of the immediate and specific material and social situation in which the text is being used and secondly from the perspective of the general believe and value system or cultural paradigm or ideology (Miller, 2005: 2 in Manfredi, 2008: 39). This explains that the immediate non-linguistic context the context of situation which is called register and the outer one is called genre. The concept which emerges from this idea is that concept is divided into co-text, register and genre.

\section{Research Method}

This study is about the types of the logical meaning existing in the wedding speeches of the Batak Toba people. It concerns with an object as multiple realities which is 
categorized as a qualitative research (Lincoln \& Guba, 1985: 40). The subject of this research are the Batak Toba people creating the wedding speeches in the wedding ceremony in three cities, they are Balige, Pematangsiantar and Medan in the province of North Sumatera in Indonesia in 2014. They belong to a speech community speaking the same language, sharing the same culture, having a native name [family name or sure name], having a social network for contact, having common folklore or history are all largely dependent on having a common mode of communication (Savile \& Troike, 1986: 17-22). The object investigated as according to Botha (1981:27) is focused on the logical meanings (Halliday, 1994) which are realized by the logico-semantic relation (LSR) of the clause complexes in the wedding speeches of the Batak Toba people. The data are 254 clause simples in 142 clause complexes. The source of the data is the transcription of 15 video recorded speeches delivered in the wedding speeches in traditional wedding parties in three cities; they are Balige, Pematangsiantar and Medan. The data collection and analysis follow the concept of the concurrent activities of a researcher in a qualitative research. Miles and Huberman (1984: 23) say that a researcher's concurrent activities are: (1) the data collection of the wedding speeches in the Batak Toba language (BTL) from the party places by a video camera (2) the data reduction for the selection of the types of the logical from the transcription of the wedding speeches, (3) the data display of each of the types of the logical meanings into tables which are provided with their word per word translation into Indonesian language (IL) and English language (EL) and the analysis of logicosemantic relation (LSR), and (4) drawing the conclusion of the the data analysis.

\section{Data Analysis}

The types of logical meanings in the wedding speeches of the Batak Toba people are classified into expansion and projection. Expansions are classified into elaboration, extension, and enhancement. Projections are classified into locution and idea.

\subsection{Elaboration}

The types of elaboration in the wedding speeches of the Batak Toba people are classified into specification, exemplification and commentary.

\subsubsection{Specification}

The types of specification in the wedding speeches of the Batak Toba people are classified into paratactic and hypotactic specification elaboration.

The type of the paratactic specification elaboration in the wedding speeches of the Batak Toba people has only one pattern, i.e., $1=2$.

Pattern: $1=2$

ljadi pangke hamuma tu angka ulaon adat, =2pangke hamuma tarlumobi angka tu ulaon ni

Table 1. Jadi pangke hamuma tu angka ulaon adat

\begin{tabular}{lllllll}
\hline BTL & jadi & pangke & hamuna & tu & angka & Ulaon \\
IL & particle & pakailah & kalian & ke & setiap & Pesta \\
EL & particle & wear & you & to & every & Party \\
TS & & process:material & actor & circumstance:place & tradition \\
LSR & 1(specified elaboration expansion) & & & \\
\hline
\end{tabular}

Table 2. Pangke hamuma tarlumobi angka tu ulaon ni hula-hula muna

\begin{tabular}{|c|c|c|c|c|c|c|c|c|c|}
\hline BTL & pangke & hamuna & tarlumobi & angka & tu & ulaon & ni & hula-hula & muna \\
\hline IL & pakai & Kalian & terlebih & setiap & ke & pesta & dari & besan & kalian \\
\hline EL & wear & you & especially & every & to & party & of & bother-in-law & you \\
\hline TS & process:material & actor & circumstan & & & & & & \\
\hline LSR & $=2($ specifying ela & expansion) & & & & & & & \\
\hline
\end{tabular}

The pattern of this logical meaning is $1=2$. In this pattern, 1 is an independent clause with a material process with a function as a specified elaboration expansion; and 2 is an independent clause with a material process with a function as a specifying elaboration expansion. Here 1 is elaborated into greater detail by 2 .
The type of the hypotactic specification elaboration in the wedding speeches of the Batak Toba people has only one pattern, i.e., $\alpha=\beta$

Pattern: $\alpha=\beta$

ajadi, pos do roha nami sude hami angka simatuam, hula- hulam sinaga = Bna adong di Balige on

Table 3. Jadi, pos do rohana mi sude hami angka simatuam

\begin{tabular}{lllllllll}
\hline BTL & jadi & pos & do & roha & nami & sude & angkka & simatua \\
IL & jadi & percaya & particle & ati & kami & semua & setiap & mertua \\
EL & particle & believe & particle & heart & we & all & every & parent-in-law \\
TS & particle & process:mental & partticle & senser & & & & \\
LSR & $\alpha$ (specified elaboration... & & & & & \\
\hline
\end{tabular}


Table 4. Hula-hulam sinaga

\begin{tabular}{lllll}
\hline BTL & hula-hulam & $\mathrm{m}$ & sinaga & na \\
IL & mertua & mu & sinaga & yang \\
EL & parent-in-law & your & sinaga & who \\
TS & senser & & \\
LSR & exansion) & & \\
\hline
\end{tabular}

Table 5. Hula- hulam sinaga na adong di balige on

\begin{tabular}{|c|c|c|c|c|}
\hline BTL & adong & di & balige & on \\
\hline IL & yang & di & balige & ini \\
\hline EL & who & in & balige & this \\
\hline TS & carrier $\quad$ procces: relational & attribute & & \\
\hline LSR & $=\beta$ (specifying elaboration expansion) & & & \\
\hline
\end{tabular}

The pattern of this logical meaning is $\alpha=\beta$. In this pattern, $\alpha$ is an independent clause with a mental process with a function as a specified elaborated expansion head; and $\beta$ as a dependent clause with a relational process with a function as a specifying elaborating expansion. Here $\alpha$ is elaborated into greater detail by $\beta$.

\subsubsection{Exemplification}

The types of the exemplification elaboration in the wedding speeches of the Batak Toba people are paratactic and hypotactic exemplification elaboration.

The type of the paratactic explication elaboration in the wedding speeches of the Batak Toba people is this pattern 1 $=2$.

Pattern $1=2$

Clause: 1tu gareja angka pangkean nabiasa ipe, $=2$ ima pangkean nasional ido pangkeon muna tu gareja

Table 6. Tu gareja angka pangkean nabiasa ipe

\begin{tabular}{|c|c|c|c|c|c|c|}
\hline BTL & tu & gereja & angka & pangkean & nabiasa & ipe \\
\hline IL & $\mathrm{ke}$ & gereja & seperti & pakaian & biasa & saja \\
\hline EL & to & curch & & dress & formal & only \\
\hline TS & car & & attribute & & & \\
\hline LSR & \multicolumn{6}{|c|}{1 (exemplified elaboration expansion) } \\
\hline
\end{tabular}

Table 7. Ima pangkean nasional i do pangkeon muna

\begin{tabular}{|c|c|c|c|c|c|c|c|}
\hline $\begin{array}{l}\text { BTL } \\
\text { IL } \\
\text { EL } \\
\text { TS } \\
\text { LSR }\end{array}$ & $\begin{array}{l}\begin{array}{l}\text { ima } \\
\text { particle } \\
\text { particle }\end{array} \\
=2(\text { exen }\end{array}$ & $\begin{array}{l}\text { pangkean } \\
\text { pakaian } \\
\text { dress } \\
\text { goal } \\
\text { ying elabor }\end{array}$ & $\begin{array}{l}\text { nasional } \\
\text { nasional } \\
\text { national } \\
\text { pansion) }\end{array}$ & particle & $\begin{array}{l}\text { pangkeon } \\
\text { pakai } \\
\text { wear } \\
\text { process: material }\end{array}$ & $\begin{array}{l}\mathrm{mu} \\
\text { kamu } \\
\text { you } \\
\text { actor }\end{array}$ & $\begin{array}{l}\text { na } \\
\text { particle } \\
\text { particle }\end{array}$ \\
\hline
\end{tabular}

The pattern of this logical meaning is $1=2$. In this pattern, 1 is an independent clause with a relational process with a function as an exemplified elaborated expansion; and $=2$ is an independent clause with a material process

with a function as the exemplifying elaborating expansion. Here 1 is elaborated by $=2$ as an example of 1 .

\subsubsection{Commentary}

Table 8. Siangkangan mai mangalap boru situmorang, $=2$ di siantar do on

\begin{tabular}{|c|c|c|c|c|c|c|c|c|}
\hline BTL & siangkangan & mai & mangalap & boru situmorang & di & siantar & do & on \\
\hline IL & tertua & & menikah & wanita marga situmorang & di & siantar & ialah & ini \\
\hline EL & the eldest & & marry & a woman of situmorang & in & siantar & is & this \\
\hline TS & actor & particle & process: material & goal & & & process: material & carrier \\
\hline LSR & \multicolumn{4}{|c|}{1 (commented elaboration expansion) } & \multicolumn{4}{|c|}{$=2($ commenting elaboration expansion) } \\
\hline
\end{tabular}

The types of the commentary elaboration in the wedding speeches of the Batak Toba people are paratactic and hypotactic elaboration expansion.

The type of the paratactic commentary elaboration in the wedding speeches of the Batak Toba people has only one pattern, i.e., $1=2$.

Pattern $1=2$

The pattern of its logical meaning is $1=2$. In this pattern,
1 is an independent clause with a material process with a function as commented elaborated expansion; and. 2 is an independent clause with a relational process with a function as a commenting elaborating expansion. Here 1 is elaborated by 2 by giving a comment to it.

The types of the hypotactic specification elaboration in the wedding speeches of the Batak Toba people in this patternis $\alpha=\beta$. 
Pattern $\alpha=\beta$

Clause: a jadi sadarion tarida do I cita-cita na saleleng on = Basa parjolo ho ale anggia

Table 9. Jadi sadarion tari do i cita-cita na saleleng on

\begin{tabular}{|c|c|c|c|c|c|c|c|c|c|c|}
\hline $\begin{array}{l}\text { BTL } \\
\text { IL } \\
\text { EL } \\
\text { TS } \\
\text { LSR }\end{array}$ & $\begin{array}{l}\text { jadi } \\
\text { particle } \\
\text { particle }\end{array}$ & $\begin{array}{l}\text { sadari on } \\
\text { hari } \quad \text { ini } \\
\text { day this } \\
\text { circumstance } \\
\text { nted elaboration }\end{array}$ & $\begin{array}{l}\text { tarida } \\
\text { kelihatan } \\
\text { appear } \\
\text { proces:relational } \\
\text { asion) }\end{array}$ & $\begin{array}{l}\text { do } \\
\text { particle } \\
\text { particle }\end{array}$ & $\begin{array}{l}\mathrm{i} \\
\text { particle } \\
\text { particle }\end{array}$ & $\begin{array}{l}\text { cita-cita } \\
\text { cita-cita } \\
\text { hope } \\
\text { carrier }\end{array}$ & $\begin{array}{l}\text { ta } \\
\text { kita } \\
\text { our }\end{array}$ & $\begin{array}{l}\text { na } \\
\text { particle } \\
\text { particle }\end{array}$ & $\begin{array}{l}\text { saleleng } \\
\text { selama } \\
\text { long }\end{array}$ & $\begin{array}{l}\text { on } \\
\text { ini }\end{array}$ \\
\hline
\end{tabular}

Table 10. Asa parjolo ho ale anggia

\begin{tabular}{|c|c|c|c|c|c|c|}
\hline BTL & asa & parjolo & ho & ale & anggi & $\mathrm{a}$ \\
\hline IL & supaya & duluan & kamu & & adik & $\mathrm{ku}$ \\
\hline EL & so & first & you & & younger sister in law & my \\
\hline TS & conjunction & attribute & carrier & voc & & \\
\hline LSR & \multicolumn{6}{|c|}{$=\beta$ (commenting elaboration expansion) } \\
\hline
\end{tabular}

The pattern of this logical meaning is $\alpha=\beta$. In this pattern, $\alpha$ is an independent clause with a relational process with a function as a commented elaborated expansion; and $\beta$ as a dependent clause with a relational process with a function as a commenting elaborating expansion. Here, $\alpha$ is elaborated by $=\beta$ by adding a comment to it.

\subsection{Extension}

The types of extension in the wedding speeches of the Batak Toba people are extension "and"; extension "or" and extension "but".

\subsubsection{Extension "and"}

The types of extension "and" in the wedding speeches of the Batak Toba people are divided into paratactic and hypotactic extension "and".

The type of paratactic extension "and" in the wedding speeches of the Batak Toba people is this pattern $1+2$.

Pattern: $1+2$

Clause:

1da hahang nadua i nungga parjolo borhat, +2songoni edamuna baomuna

Table 11. Da hahang nadua i nungga parjolo borhat

\begin{tabular}{llllll}
\hline BTL & dahahang & nadua & i & nungga & parjolo \\
IL & abang & dua & itu & telah & borhat \\
EL & elder brother & two & the & has & firstly \\
circustance
\end{tabular}

Table 12. Songoni edamuna baomuna

\begin{tabular}{|c|c|c|c|c|}
\hline BTL & songoni & $\mathrm{mu}$ & bao & $\mathrm{mu}$ \\
\hline IL & besan & kalian & besan & kalian \\
\hline EL & sister-in-law & your & sister-in-law & your \\
\hline TS & conjunction & & & \\
\hline LSR & +2 (extended"and"expansion) & & & \\
\hline
\end{tabular}

The pattern of this logical meaning in this text is $1+2$. In this pattern, 1 is an independent clause with a relational process with a function as an extended "and" expansion; and 2 is an elliptical independent extension "and" clause functions as an extending "and" expansion. Here 1 is extended by +2 .

\subsubsection{Extension "but"}

The type of extension "but" only has the paratactic extension "but" in the wedding speeches of the Batak Toba people is this pattern $1+2$.

Pattern: $1+2$

Clause:

Iholan tu adat do boanon muna on ate, +2dang pola boanon muna on dohot tu gareja

Table 13. Holan tu adat do boanon muna on ate

\begin{tabular}{|c|c|c|c|c|c|c|c|c|}
\hline BTL & holan & tu & adat & do & boanon & muna & on & ate \\
\hline IL & hanya & ke & adat & nya & bawa & kalian & ini & \\
\hline EL & only & to & party & & wear & you & this & \\
\hline TS & circuns & & & particle & process:material & actor & goal & \\
\hline LSR & 1 (exte & but" & & & & & & \\
\hline
\end{tabular}


Table 14. Dang pola boanon muna on dohot tu gareja

\begin{tabular}{lllllll}
\hline BTL & dang & pola & boanon & muna & on & dohot \\
IL & tidak & & pakai & kalian & ini & gareja \\
EL & not & waer & you & this & gereja \\
TS & process:material & & actor & goal & circumstance \\
LSR & +2 (extending "but" expansion) & & & & & \\
\hline
\end{tabular}

The pattern of this logical meaning is $1+2$. In this pattern, 1 is an independent clause with a material process with a function as an extended expansion; and +2 is an independent clause with a material process with a function as an extending "but" expansion. Here 1 is extended by 2 .

\subsection{Enhancement}

The types of enhancement in the wedding speeches of the Batak Toba people are spatial enhancement, temporal enhancement, conditional enhancement, causal enhancement, concessive enhancement, and manner enhancement.

\subsubsection{Spatial Enhancement}

The types of spatial enhancement in the wedding speeches of the Batak Toba people are divided into paratactic and hypotactic spatial enhancement.

The type of the paratactic spatial enhancement in the wedding speeches of the Batak Toba people is this $1 \times 2$.

Pattern: 1 x2

Clause:

ISMA ibana x2di asrama do

Table 15. Sma ibana

\begin{tabular}{lll}
\hline BTL & sma & ibana \\
IL & sma & dia \\
EL & senior middle high school & she \\
TS & attribute & carrier \\
LSR & 1 (enhanced expansion) & \\
\hline
\end{tabular}

Table 16. Di asrama do

\begin{tabular}{llll}
\hline BTL & di & asrama & do \\
IL & di & asrama & particle \\
EL & in & hostel & particle \\
TS & attribute & \\
LSR & x2 (elliptical spatial enhancing expansion) & \\
\hline
\end{tabular}

The pattern of this logical meaning is $1 \times 2$. In this pattern, 1 is an independent clause with a relational process with a function as an enhanced expansion; and $\mathrm{x} 2$ is an elliptical independent clause with a relational process with a function as spatial enhancing expansion. Here, 1 is spatially enhanced by 2 .

The type of the hypotactic spatial enhancement in the wedding speeches of the Batak Toba people is this pattern $\alpha$ $\mathrm{x} \beta$.

Pattern: $\alpha \times \beta$

Clause:

apos rohanami, xßnang di tangiang nami nainggkon gabe keluarga namarbahagia hamu

Table 17. Pos rohanami

\begin{tabular}{llll}
\hline BTL & pos & roha & nami \\
IL & yakin & hati & kami \\
EL & sure & heart & our \\
TS & attribute & carrier & \\
LSR & $\alpha$ (enhanced expansion) & & \\
\hline
\end{tabular}

Table 18. nang di tangiang nami nainggkon gabe keluarga namarbahagia hamu (modifier: xßas a dependent spatial enhancement clause)

\begin{tabular}{|c|c|c|c|c|c|c|c|c|c|}
\hline $\begin{array}{l}\text { BTL } \\
\text { IL } \\
\text { EL } \\
\text { TS } \\
\text { LSR }\end{array}$ & $\begin{array}{l}\text { nang } \\
\text { seperti } \\
\text { as } \\
\text { conjunction } \\
\beta \text { (spatial en }\end{array}$ & $\begin{array}{l}\text { di } \\
\text { dalam } \\
\text { in } \\
\text { attribute } \\
\text { ncing expa }\end{array}$ & $\begin{array}{l}\text { tangiang } \\
\text { doa } \\
\text { player }\end{array}$ & $\begin{array}{l}\text { nami } \\
\text { kami } \\
\text { our }\end{array}$ & $\begin{array}{l}\text { naingkon } \\
\text { harus } \\
\text { must } \\
\text { process:re }\end{array}$ & $\begin{array}{l}\text { gabe } \\
\text { jadi } \\
\text { be }\end{array}$ & $\begin{array}{l}\text { keluarga } \\
\text { keluarga } \\
\text { family } \\
\text { carrier }\end{array}$ & $\begin{array}{l}\text { namarbahagia } \\
\text { berbahagia } \\
\text { happy }\end{array}$ & $\begin{array}{l}\text { hamu } \\
\text { kalian } \\
\text { you }\end{array}$ \\
\hline
\end{tabular}

The pattern of this logical meaning is $\alpha \times \beta$. In this pattern, $\alpha$ is an independent clause with a relational process with a function as an enhanced clause; and $\beta$ is a dependent spatial enhancement clause with a relational process with a function as the modifier. Here, $\alpha$ is enhanced by $\beta$.

\subsubsection{Temporal Enhancement}

The types of temporal enhancement in the wedding speeches of the Batak Toba people are the hypotactic 
temporal enhancement.

The type of the hypotactic temporal enhancements in the wedding speeches of the Batak Toba people is this pattern $\alpha$ $\mathrm{x} \beta$.

Pattern: $\alpha \times \beta$

Table 19. Tontu martangiang $x \beta$ tinggki margareja,

\begin{tabular}{lllll}
\hline BTL & tontu & martangiang & tingki & margareja \\
IL & & berdoa & ketika & di gereja \\
EL & & pray & when & in church \\
TS & particle & process: verbal & conjunction & attribute \\
LSR & $\alpha$ (enhanced expansion) & $x \beta$ (enhancing expansion) & \\
\hline
\end{tabular}

The pattern of this logical meaning is $\alpha \times \beta$. In this pattern, $\alpha$ is an independent clause with a verbal process with a function as an enhanced expansion; andx $\beta$ is a dependent clause with a relational process with a function as enhancing expansion. Here $\alpha$ is enhanced by $\beta$ with a temporal enhancement.

\subsubsection{Conditional Enhancement}

The type of conditional enhancement in the wedding speeches of the Batak Toba people has paratactic and hypotactic temporal enhancement.

The type of paratactic enhancement in the wedding speeches of the Batak Toba people is pattern $\mathrm{x} 12$.

Pattern 1: x1 2

Clause:

xlalai di bagasan ni parjoloma hamuna mangalului harajaon ni Debata, 2baru ma annon pasahaton nama angka ondeng

Table 20. Alai di bagasan ni parjoloma hamuna mangalului harajaon ni Debata

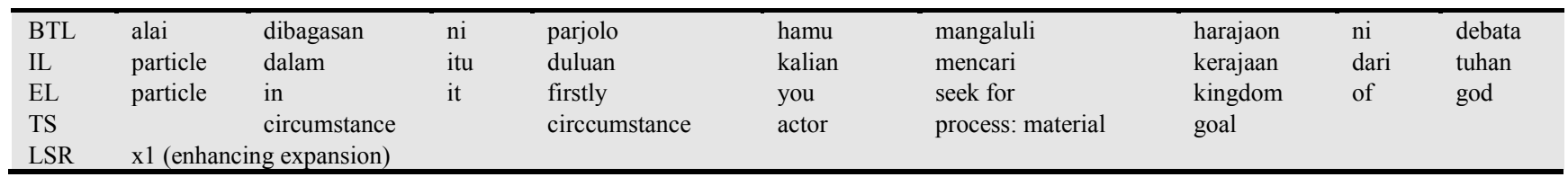

Table 21. Baru ma annon pasahaton nama angka ondeng

\begin{tabular}{lllllll}
\hline BTL & baru & ma & annon & pasahaton & nama & angka \\
IL & kemudian & lah & nanti & memberikan & lah & ondeng \\
EL & then & particle & soon & give & particle & every \\
TS & conjunction & & circumstance & process: material & & goal \\
LSR & 2 (enhanced expansion) & & & & \\
\hline
\end{tabular}

The patterns of this logical meanings is $\mathrm{x} 12$. In this pattern, $x 1$ is an independent conditional clause with a mental process with a function as an enhancing expansion; and 2 is an independent clause with a relational process with a function as an enhanced expansion. Here, $\mathrm{x} 1$ is enhanced by conditionally.

The type of hypotactic enhancement in the wedding speeches of the Batak Toba people is the pattern $\alpha \times \beta$.

Pattern: $\alpha \times \beta$

Clause:

aanggo angka hamoraon ido, anggo angka arta $i$, mangihut doi sian pudi, $x \beta$ asalma dos roha muna tentang keluarga muna

Table 22. Anggo angka hamoraon ido, anggo angka arta $i$

\begin{tabular}{|c|c|c|c|c|c|c|c|c|c|}
\hline BTL & anggo & angka & hamoraon & $\mathrm{i}$ & do & anggo & angka & arta & $\mathrm{i}$ \\
\hline IL & particle & setiap & kekayaan & particle & particle & particle & setiap & harta & particle \\
\hline EL & particle & every & wealth & particle & particle & particle & every & property & particle \\
\hline TS & & carrier & & & & & & & \\
\hline LSR & $\alpha$ (enhan & & & & & & & & \\
\hline
\end{tabular}

Table 23. Mangihut doi sian pudi (head: aas an independent clause)

\begin{tabular}{llllll}
\hline BTL & mangihut & do & i & sian & pudi \\
IL & datang & particle & particle & di & kemudian hari \\
EL & comes & particle & particle & in the future \\
TS & process: material & & & circumstance \\
LSR & expansion & & & \\
\hline
\end{tabular}


Table 24. Asalma dos roha muna tentang keluarga muna

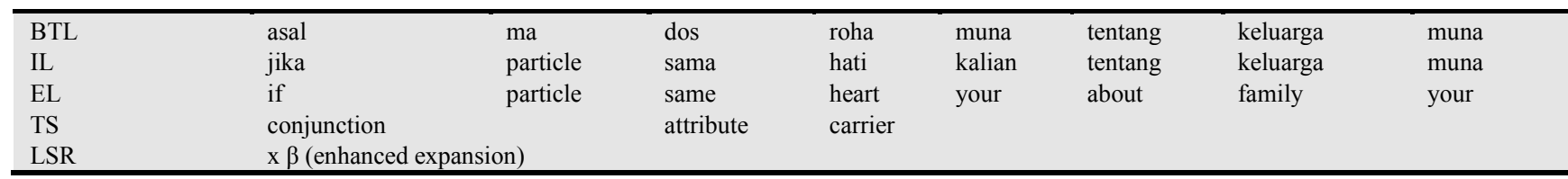

The pattern of this logical meaning is $\alpha \times \beta$. In this pattern $\alpha$ is an independent clause with a relational process with a function as the head; and 2 is a dependent clause with a relational process with a function as the modifier.

Here, $\alpha$ is enhanced by $\beta$ conditionally.

Pattern: $\mathrm{x} \beta \alpha$

Clause:

$x \beta$ atik adong na hurang da, aleon hatorangan

Table 25. Atik adong na hurang da

\begin{tabular}{lllll}
\hline BTL & atik & adong & na & hurang \\
IL & jika & ada & particle & kurang \\
EL & if & is & particle & wrong \\
TS & conjunction & process: relational & attribute \\
LSR & x $\beta$ (enhanced expansion) & & & particle \\
\hline
\end{tabular}

Table 26. Leon hatorangan

\begin{tabular}{lll}
\hline BTL & leon & hatorangan \\
IL & berikan & keterangan \\
EL & give & explanation \\
TS & procces:verbal & verbaige \\
LSR & & \\
\hline
\end{tabular}

The pattern of this logical meaning is $\mathrm{x} \beta \alpha$. In this pattern $x \beta$ is a dependent clause with a relational process with a function as an enhancing expansion; and $\alpha$ is an independent clause with a verbal process with a function as an enhanced expansion. Here, $x \beta \alpha$ is enhanced by $\beta$ temporarily.

\subsubsection{Causal Enhancement}

The type of causal enhancement in the wedding speeches of the Batak Toba people has paratactic and hypotactic causal enhancement.

The type of paratactic causal enhancement in the wedding speeches of the Batak Toba people is this pattern 1 $\mathrm{x} 2$.

Pattern: 1 x2

Clause:

lima patuduhon las ni roha nami, x2di naung pajonjongkon pardongan saripeon hamuna

Table 27. Ima patuduhon las ni roha nami

\begin{tabular}{llllll}
\hline BTL & ima & patuduhon & las & ni & roha \\
IL & itulah & memunjukan & kegembiraan & dari & hati \\
EL & that & shows & happiness & of & heart \\
TS & & process: material & goal & \\
LSR & 1 (enhanced expansion) & & \\
\hline
\end{tabular}

Table 28. Di naung pajonjongkon pardongan saripeon hamuna

\begin{tabular}{|c|c|c|c|c|c|}
\hline BTL & di & naung & pajongjongkon & pardongan saripeon & hamu \\
\hline IL & particle & telah & mendirikan & keluara & kalian \\
\hline EL & particle & have & got & marriage & you \\
\hline TS & \multicolumn{3}{|c|}{ process:relational } & attribute & carrier \\
\hline LSR & \multicolumn{5}{|c|}{ x2(enhancing expansion) } \\
\hline
\end{tabular}

The pattern of this logical meaning is $1 \times 2$. In this pattern, 1 is an independent clause with a material process with a function as an enhanced expansion; and 2 is an independent clause with a relational process with a function as an enhancing expansion. Here, 1 is enhanced by $x 2$ causally.
Pattern: x12

Clause:

xlpasahatonnami ma ulos ${ }^{8}$ naganjang on 2 asa ganjang ma barita nauli, barita horas di hamuna keluarga sidabutar tu joloan ni arion 
Table 29. Pasahatonnami ma ulos ${ }^{8}$ naganjang on

\begin{tabular}{lllllll}
\hline BTL & pasahaton & nami & ma & ulo & naganjang & on \\
IL & menyampaikan & kami & akan & kain & panjang & ini \\
EL & give & we & are & cloth & long & this \\
TS & process: material & actor & & & \\
LSR & 1 (enhancing expansion) & & & & \\
\hline
\end{tabular}

Table 30. Asa ganjang ma barita nauli barita horas

\begin{tabular}{llllllll}
\hline BTL & asa & ganjang & ma & barita & nauli & barita & horas \\
IL & agar & panjang & lah & berita & baik & berita & gembira \\
EL & so & long & & messege & good & messege & happy \\
TS & conjunction & attribute & particle & carrier & & & \\
LSR & 2 (enhanced..... & & & & & & \\
\hline
\end{tabular}

Table 31. Di hamuna keluarga sidabutar tu joloan ni arion

\begin{tabular}{|c|c|c|c|c|c|c|c|c|c|}
\hline BTL & di & hamu & keluarga & sidabutar & tu & joloan & ni & ari & on \\
\hline IL & pada & kalian & keluarga & sidabutar & di & kemudian & dari & hari & ini \\
\hline EL & in & your & sidabutar & family & in & future & of & day & this \\
\hline TS & \multirow{2}{*}{\multicolumn{4}{|c|}{$\begin{array}{l}\text { circumstance: spatial } \\
\text {...expansion) }\end{array}$}} & \multirow{2}{*}{\multicolumn{5}{|c|}{ cirstumstance: temporal }} \\
\hline LSR & & & & & & & & & \\
\hline
\end{tabular}

The pattern of this logical meaning is $\mathrm{x} 12$. In this pattern, $\mathrm{x} 1$ is an independent clause with a material process with a function as an enhancing enhancement; and 2 is an independent clause with a relational process with a function as an enhanced clause. Here, $x 1$ enhances 2 causally.

\subsubsection{Hypotactic Causal Enhancement}

The type of hypotactic causal enhancement in the wedding speeches of the Batak Toba people is this pattern $\alpha$ $\mathrm{x} \beta$

Pattern: $\alpha \times \beta$

Clause:

amandok mauliate ma hita tu Tuhanta, x Bala nungga saut nasinangkapan ni rohamuna

Table 32. Mandok mauliate ma hita tu Tuhanta

\begin{tabular}{llllllll}
\hline BTL & mandok & mauliate & ma & hita & tu & tuhan & ta \\
IL & mengucapkam & terimakasih & particle & hita & ke & tuhan & kita \\
EL & say & thanks & particle & we & to & god & our \\
TS & process: verbal & verbiage & & sayer & receiver & & \\
LSR & $\alpha$ (enhanced expansion) & & & & & & \\
\hline
\end{tabular}

Table 33. Ala nungga saut nasinangkapan ni rohamuna

\begin{tabular}{llllllll}
\hline BTL & ala & nungga & saut & nasinangkapan & ni & roha & muna \\
IL & karena & sudah menjadi & benar & keinginan & dari & hati & kalian \\
EL & because & has become & true & desire & of & heart & your \\
TS & conjunction & process: relational & attribute & carrier & & & \\
LSR & $\times \beta$ (enhancing expansion) & & & & \\
\hline
\end{tabular}

The pattern of this logical meaning is $\alpha \times \beta$. In this pattern, $\alpha$ is an independent causal clauses with verbal processes function as an enhanced expansion; and $\mathrm{x} \beta$ is a dependent causal enhancement clause with mental process with a function as an enhancing expansion. Here $\alpha$ is enhanced causally by $x \beta$.

\subsubsection{Concessive Enhancement}

The type of concessive enhancement in the wedding speeches of the Batak Toba people has only hypotacic concessive enhancement as in the followings.

\subsection{Hypotactic Concessive Enhancement}

The type of concessive enhancement in the wedding speeches of the Batak Toba people is this pattern $\mathrm{x} \beta \alpha$.

Pattern: $x \beta \alpha$

Clause:

$x \beta$ anting tung son go nape tipis do hot heal ni ulos ${ }^{8}$ on alas ma roha ni badanmuna 
Table 34. Antong tung songo nipe tipis dohot hapal ni ulos ${ }^{8}$ on

\begin{tabular}{|c|c|c|c|c|c|c|c|c|c|c|}
\hline $\begin{array}{l}\text { BTL } \\
\text { IL } \\
\text { EL } \\
\text { TS } \\
\text { LSR }\end{array}$ & $\begin{array}{l}\text { particle } \\
x \beta \text { (enh }\end{array}$ & $\begin{array}{l}\text { tung } \\
\text { walaupun } \\
\text { although } \\
\text { conjunction } \\
\text { g enhanceme }\end{array}$ & $\begin{array}{l}\text { songon } \\
\text { demikian } \\
\text { so } \\
\text { attribute }\end{array}$ & $\begin{array}{l}\text { ipe } \\
\text { particle } \\
\text { particle }\end{array}$ & $\begin{array}{l}\text { tipis } \\
\text { tipis } \\
\text { thinness } \\
\text { carrier }\end{array}$ & $\begin{array}{l}\text { dohot } \\
\text { dan } \\
\text { and }\end{array}$ & $\begin{array}{l}\text { hapal } \\
\text { tebal } \\
\text { thickness }\end{array}$ & $\begin{array}{l}\text { ni } \\
\text { nya } \\
\text { its }\end{array}$ & $\begin{array}{l}\text { ulos } \\
\text { kain } \\
\text { cloth }\end{array}$ & $\begin{array}{l}\text { on } \\
\text { ini } \\
\text { this }\end{array}$ \\
\hline
\end{tabular}

Table 35. Las ma roha ni badanmuna

\begin{tabular}{lllllll}
\hline BTL & las & ma & roha & ni & badan & muna \\
IL & bergembira & lah & hati & dari & badan & kalian \\
EL & happy & & heart & of & body & you \\
TS & attribute & particle & & & & \\
LSR & $\alpha$ (enhanced expansion) & & & & & \\
\hline
\end{tabular}

The pattern of this logical meaning is $x \beta \alpha$. In this pattern, $x \beta$ is a dependent clause with a relational process with a function as an enhancing expansion; and $\alpha$ is an independent clause with mental process with a function as an enhancing expansion. Here, $x \beta$ enhances $\alpha$ concessively.

\subsubsection{Manner Enhancement}

The type of manner enhancement in the wedding speeches of the Batak Toba people has only hypotactic manner enhancement.

The type of manner enhancement in the wedding speeches of the Batak Toba people is this pattern $\alpha \times \beta$.

Pattern: $\alpha \times \beta$

Clause:

andang hea iboto x $\beta$ mangalompa

Table 36. Dang hea iboto

\begin{tabular}{llll}
\hline BTL & dang & hea & iboto \\
IL & tidak & pernah & tahu \\
EL & doesn't & ever & know \\
TS & & cirsustance & \\
LSR & process: mental & & \\
\hline
\end{tabular}

Table 37. Mangalompa

\begin{tabular}{ll}
\hline BTL & mangalompa \\
IL & memasak \\
EL & cook \\
TS & process: material \\
LSR & $x \beta$ (enhancing expansion) \\
\hline
\end{tabular}

The pattern of this logical meaning is $\alpha \times \beta$. In this pattern, $\alpha$ is an independent clauses with a mental process with a function as the modifier, and $\mathrm{x} \beta$ is a dependent manner enhancement clause with a material process with a function as the modifier. Here $\alpha$ is enhanced by $x \beta$ mannerly.

\subsection{Projection}

The type of projection in the wedding speeches of the Batak Toba people has three types, i.e., locution projection, idea projection and idea.
The type of locution in the wedding speeches of the Batak Toba people has paratactic and hypotactic locution as in the followings.

\subsubsection{Paratactic Locution}

The type of paratactic locution in the wedding speeches of the Batak Toba people has this pattern 1 " 2 .

Pattern: 1 "2

Clause:

1saonnari dohonon nami ma ulos pansamot ${ }^{9}$ di laemi dohot ibotonami dison, "2passamot angka nauli nadenggan ma on dikeluarga ni laengku ibotongku

\subsubsection{Locution}

Table 38. Saonnari dohonon nami ma ulos pansamot ${ }^{9}$ di laemi dohot ibotonami dison saonnari dohonon nami ma ulos pansamot ${ }^{9}$

\begin{tabular}{lllllll}
\hline BTL & saonari & dohonon & nami & ma & ulos & pansamot \\
IL & sekarang & mengatakan & kami & lah & kain & pemmbuat \\
EL & now & say & we & & cloth & maker \\
TS & circumstance & process: verbal & sayer & & target & \\
LSR & 1 (projecting..... & & & & \\
\hline
\end{tabular}


Table 39. Di laemi dohot ibotonami dison

\begin{tabular}{lllllll}
\hline BTL & di & lae & mi & dohot & iboto & nami \\
IL & kepada & besan & kami & dan & besan & kami \\
EL & to & brother-in-law & our & dan & siste-in-law & our \\
TS & recipient & & & & here \\
LSR & clause) & & & & \\
\hline
\end{tabular}

Table 40. Passamot angka nauli nadenggan ma on dikeluarga ni laengku ibotongku passamot angka nauli nadenggan ma on

\begin{tabular}{llllll}
\hline BTL & passamot & angka & nauli & nadenggan & ma \\
IL & pembuat & setiap & baik & indah & lah \\
EL & maker & every & good & kind & particle \\
TS & carrier & attribute & & particle \\
LSR & "2 (projected... & & & particle \\
\hline
\end{tabular}

Table 41. Dikeluarga ni laengku ibotongku

\begin{tabular}{lllllll}
\hline BTL & di & keluarga & ni & lae & ngku & iboto \\
IL & dalam & family & dari & besan & saya & besan \\
EL & in & family & of & brother-in-law & my & sister-in-law \\
TS & circumstance: space & & & & my \\
LSR & clause) & & & & & \\
\hline
\end{tabular}

The pattern of this logical meaning is 1 " 2 . In this pattern, 1 is an independent projecting clause with a verbal process with a function as the modifier; and " 2 is an independent projected clause with a relational process with a function as the head. Here 1 projects " 2 .

\subsubsection{Hypotactic Locution}

The type of hypotactic locution in the wedding speeches of the Batak Toba people has this pattern $\alpha$ " $\beta$.

Pattern: $\alpha$ " $\beta$

Clause:

amandok mauliate ma hita tu Tuhanta, "Bala nungga dioloi sangkap ni rohamuna $i$

Table 42. Mandok mauliatema hita tu Tuhanta

\begin{tabular}{lllllll}
\hline BTL & mandok & mauliat & ma & hita & tu & tuhan \\
IL & mengatakan & terimakasih & particle & kita & ke & tahan \\
EL & say & thanks & particle & we & to & god \\
TS & process: verbal & verbiage & & sayer & reciever \\
LSR & 1 (projecting clause) & & & & \\
\hline
\end{tabular}

Table 43. Ala nungga dioloi sangkap ni rohamunai

\begin{tabular}{|c|c|c|c|c|c|c|c|}
\hline BTL & ala & nungga & dioloi & sangkap & ni & roha & munai \\
\hline IL & karena & telah & direstui & keinginan & dari & hati & kalian \\
\hline EL & because & has been & accepted & hope & of & heart & your \\
\hline TS & conjunction & process: mental & & hope & of & heart & your \\
\hline LSR & " $\beta$ (projected clause) & & & & & & \\
\hline
\end{tabular}

The pattern of the logical meaning in this text is $\alpha$ " $\beta$. In this pattern, $\alpha$ is an independent clause with a function as a projecting clause; and $\beta$ is a dependent clause with a function as a projected clause. Here $\beta$ is projected by $\alpha$.

\subsubsection{Idea}

The type of idea in the wedding speeches of the Batak Toba people has paratactic and hypotactic idea.

\subsubsection{Paratactic Idea}

The type of paratactic idea in the wedding speeches of the Batak Toba people has this pattern 1 " 2 .

Pattern:1 "2

Clause:

Imartangiangma hita, "2asa anggiat gabe keluarga namarbahagia nasida

Table 44. Martangiangma hita

\begin{tabular}{llll}
\hline BTL & martangiang & ma & hita \\
IL & berdoa & lah & kita \\
EL & pray & & we \\
TS & process: mental & & senser \\
LSR & 1 (projrcting clause) & \\
\hline
\end{tabular}


Table 45. Asa anggiat gabe keluarga namarbahagia nasida

\begin{tabular}{llllll}
\hline BTL & asa & anggiat & gabe & keluarga & nanarbahagia \\
IL & agar & semoga & menjadi & keluarga & nerbahagia \\
EL & so & may & become & famiy & happy \\
TS & conjunction & process: relational & attribute & mereka \\
LSR & & & & & carrier \\
\hline
\end{tabular}

The pattern of this logical meaning is 1 ' 2 . In this pattern, 1 is an independent projecting clause with a mental process with a function as the modifier; and ' 2 as an independent projected idea proposition clause with a relational process with a function as the head. Here 1 projects ' 2 .

\subsubsection{Hypotactic Idea}

The type of hypotactic idea in the wedding speeches of the Batak Toba people has this pattern $\alpha$ ' $\beta$.

Pattern: $\alpha$ ' $\beta$

Clause:

a martangiang hita tu Debata, 'Basa dipasaut sude angka nasinangkapan ni rohanta

Table 46. Martangiang hita tu Debata

\begin{tabular}{llllll}
\hline BTL & martangiang & hita & tu & tuhan \\
IL & berdoa & kita & kepada & tuhan \\
EL & pray & we & ro & god \\
TS & process: mental & senser & circumstance & & our \\
LSR & $\alpha$ (projecting clause) & & & \\
\hline
\end{tabular}

Table 47. Asa dipasaut sude angka nasinangkapan ni rohanta

\begin{tabular}{|c|c|c|c|c|c|c|c|c|}
\hline $\begin{array}{l}\text { BTL } \\
\text { IL }\end{array}$ & $\begin{array}{l}\text { asa } \\
\text { agar }\end{array}$ & $\begin{array}{l}\text { dipasaut } \\
\text { dijadikan }\end{array}$ & $\begin{array}{l}\text { sude } \\
\text { semua }\end{array}$ & $\begin{array}{l}\text { angka } \\
\text { setiap }\end{array}$ & $\begin{array}{l}\text { nasinangkap } \\
\text { direncanakan }\end{array}$ & $\begin{array}{l}\text { ni } \\
\text { dari }\end{array}$ & $\begin{array}{l}\text { rohan } \\
\text { hati }\end{array}$ & $\begin{array}{l}\text { ta } \\
\text { kita }\end{array}$ \\
\hline EL & so & accepted & all & every & hope & of & heart & our \\
\hline TS & conjunction & procces: mental & all & every & phenemon & & & \\
\hline LSR & $\beta$ (projected clause) & & & & & & & \\
\hline
\end{tabular}

The pattern of this logical meaning in this text is $\alpha$ ' $\beta$. In this pattern, $\alpha$ is an independent projecting clause with a mental process with a function as the modifier; and ' $\beta$ is a dependent projected idea: projection clause with a mental process with a function as the head. Here $\alpha$ projects ' $\beta$.

\subsubsection{Idea: Proposition}

The type of idea: locution in the wedding speeches of the Batak Toba people has paratactic and hypotactic idea: locution.

\subsubsection{Paratactic Idea: Proposition}

The type of paratactic idea: locution in the wedding speeches of the Batak Toba people has this pattern 1 ' 2 .

Pattern: 1 '2

Clause:

1pos roha muna, '2sai diramoti ma hamu di parkarejoan muna

Table 48. Pos roha muna

\begin{tabular}{llll}
\hline BTL & pos & roha & muna \\
IL & yakin & hati & kalian \\
EL & sure & heart & you \\
TS & attribute & carrier & \\
LSR & 1(projecting clause) & & \\
\hline
\end{tabular}

Table 49. Sai diramoti ma hamu di parkarejoan muna

\begin{tabular}{llllllll}
\hline BTL & sai & diramoti & ma & hamu & di & pakarejoan & muna \\
IL & semoga & dilindungi & lah & kalian & di & pekerjan & kalian \\
EL & may & protected & & you & at & work & your \\
TS & process: mental & particle & phenomenon & circumstance & \\
LSR & 2(projected idea : proposition) & & & & \\
\hline
\end{tabular}

The pattern of this logical meaning is 1 ' 2 . In this pattern, 1 is an independent projecting clause with a mental process with a function as the modifier; and ' 2 is an independent projected idea proposition clause with a mental process with a function as the head. Here 1 projects ' 2 .

\subsubsection{Hypotactic Idea: Proposition}

The type of hypotactic idea: locution in the wedding speeches of the Batak Toba people has this pattern ' $\beta \alpha$.

Pattern: ' $\beta \alpha$

Clause: 
' $\beta$ ulos-ulos ${ }^{10}$ mu songon ulos $^{8}$ ni anakmu siampudani do $\quad \alpha$ hubaen

Table 50. Ulos-ulos mu songon ulos ${ }^{8}$ ni anakmu siampudan $i$ do

\begin{tabular}{llllllllll}
\hline BTL & ulos-ulos & mu & songon & ulos & ni & anak & mu & siampudan & i \\
IL & kain & mu & seperti & kain & dari & anak & mu & bungsu & do \\
EL & cloth & your & is & cloth & of & son & your & youngest son \\
TS & carrier & & process: relational & attribute & & & & & \\
LSR & $\beta$ (projected clause) & & & & & & \\
\hline
\end{tabular}

Table 51. Hu baen

\begin{tabular}{lll}
\hline BTL & Hu & Baen \\
IL & Saya & Buat \\
EL & I & Make \\
TS & Senser & Process:mental \\
LSR & A (projecting clause) & \\
\hline
\end{tabular}

The pattern of this logical meaning is ' $\beta \alpha$. In this pattern, ' $\beta$ is a dependent projected idea proposition clause with a relational process with a function as the head; and $\alpha$ is an independent projecting clause with a mental process with a function as the modifier. Here ' $\beta$ projects $\alpha$.

\subsection{Findings and Discussion}

\subsubsection{Findings}

The types of the logical meanings in the wedding speeches of the Batak Toba people are classified into expansions and projections.

1. The expansions in the wedding speeches of the Batak Toba people are classified into elaboration, extension, and enhancement.

2. The projection in the wedding speeches of the Batak Toba people are classified into locution projection, idea projection and idea

The type of the logical meaning in the wedding speeches of the Batak Toba people is created by the logico-semantic relation in the tactic system.

1. The expansions i.e. elaboration, extension, and enhancement in the wedding speeches of the Batak Toba people is created in both the paratactic and hypotactic system.

2. The projection i.e. locution projection, idea projection and idea in the wedding speeches of the Batak Toba people is created in both the paratactic and hypotactic system.

\subsubsection{Discussion}

The findings in this research indicate that Batak Toba language constitutes some similarities with the other language in the expression of human experience through the ideational function of language. It constitutes some similarities in the structure of their logical meanings realized by the clause complexes. These findings conform to the application of functional grammar theories to the data collection, data selection, and data analysis in this research. The analysis of the structure of each type of the logical meanings is under the orientation of the logicosemantic relation. The analysis is conducted based on the bottom-up approach to come along with the concept of functional grammar claiming that the meaning is created by the language in the context in where it is used. In this research, the context analyzed in where the meaning is created is the linguistic context. By this approach, the findings of this research reveal out that there is a strong similarity among the characteristics of the language in this world.

The analysis of the structure of the logical meanings in this research moves from the data under the orientation of the logico-semantic relation. It is claimed that the lack of this approach is that the linguistic context analysis only provides a part of the meaning of the structure. It means that it does not cover the other contextual meanings contributed by the ones like the context of culture, text purpose, ideology, etc. Any how the strength of this analytical approach provides consistent information of linguistic meanings which can provide enough schemes for following any possible meaning expansion and projection in accordance with the ready context.

\section{Conclusion and Suggestion}

\subsection{Conclusion}

There is a general similarity in the concept of logical meanings in Batak Toba language and the other languages in this world. Batak Toba language also has logical meanings. They are expansions such as elaboration, extension and enhancement; and they are projection such as locution projection, idea projection and idea. These logical meanings are realized by the logico-semantic relation of clause simples in a clause complex in Batak Toba language.

\subsection{Suggestion}

This research needs to be reflicated in the other language events in Batak Toba language. It also needs to be relicated in the other Austronesian languages. The findings are important information for strengthening the similarities among the languages in this world. They are important for understanding language production and interpretation. They are very important to understand that language and meaning are created in linguistic context. 


\section{References}

[1] Botha, Rudolf P. 1981. The Conduct of Linguistic Inquiry: A Systematic Introduction to the Methodology of Generative Grammar. New York: Mouton Publishers.

[2] Halliday, M. \& Hasan, R. (1976). Cohesion in English. London: Longman.

[3] Halliday, M. 1985/1994. An introduction to functional grammar. London: Edward Arnold.

[4] Halliday, M.A.K. 1994. Functional Grammar. $2^{\text {nd }}$ Edition. London: Edward Arnold.

[5] Hasan, Ruqaiya and M.A.K. Halliday. 1985. Language, Context, and Text: Aspects of Language in a Social-semiotic Perspective. Geelong, Vic: Deakin University Press. $2^{\text {nd }}$ edition, 1989, Oxford: OUP.

[6] Hatim, B. \& Mason, I. 1990. Discourse and the translator. London: Longman.

[7] Manfredi, Marina. (2008). Translating Text: Translation Studies and Systemic Functional Linguistics. Vol. I Translation Theory. Bologna: dupress.

[8] Lincoln, Yvonna S. \& Guba, Egon G. 1985. Naturalistic Inquiry.Beverly Hills California: Sage Publication, Inc.

[9] Miles, M. B. And Huberman, A.M. 1984. Qualitative Data Analysis: London: Sage Publication

[10] Miller, D.R. with the collaboration of Maiorani, A. \& Turci, M. (2005), Language as Purposeful: Functional Varieties of Texts, Quarderni del CeSLiC: Functional Grammar Studies for Non-Native Speakers of English, Series Editor, Donna R. Miller, Alma DL. Bologna: Asterisco. (Electronicversion:http://amsacta.cib.unibo.it/arcive/000086).

[11] Newbert, A. \& Gregory M. S. 1992. Translation as Text. The Kent State University Press. NORD C

[12] Saville, Mauriel \& Troike. 1986. The Ethnography of Communication: An Introduction. Oxford: Basil Blackwell, Ltd. 